\title{
STRATEGI PENGEMBANGAN KEGIATAN EKONOMI KREATIF PKK DI KOTA TABANAN TERHADAP PENINGKATAN PENDAPATAN ANGGOTA
}

\author{
I Gusti Agung Nyoman Dananjaya"), Pande Komang Suparyana ${ }^{\left.2^{*}\right)}$, I Made Dedy Setiawan ${ }^{3)}$, \\ I Gusti Ayu Diah Yuniti ${ }^{4)}$ \\ ${ }^{1}$ Universitas Dwijendra \\ ${ }^{2}$ Universitas Mataram \\ ${ }^{3}$ STMIK STIKOM Indonesia \\ ${ }^{4}$ Universitas Mahasaraswati Denpasar
}

${ }^{*}$ Corresponding author : pandesuparyana@unram.ac.id

To cite this article:

Dananjaya, I., Suparyana, P., Setiawan, I., \& Yuniti, I. (2020). Strategi Pengembangan Kegiatan Ekonomi Kreatif PKK di Kota Tabanan terhadap Peningkatan Pendapatan Anggota. JIA (Jurnal IImiah Agribisnis) : Jurnal Agribisnis dan IImu Sosial Ekonomi Pertanian, 5(6), 207 - 221. doi:http://dx.doi.org/10.37149/jia.v5i6.15083

Received: November 16, 2020; Accepted: December 29 2020; Published: December 31, 2020

\section{ABSTRACT}

The female workforce has productivity that plays a role and has the potential to support increased household income in rural areas. To provide guidance for women's productivity, a forum in the form of a PKK is needed that can be used by women. The purpose of this study was to identify the internal and external conditions of the PKK, as well as to determine the strategies that the PKK could use in Tabanan City in developing creative economic activities to increase member income. This research was conducted in Tabanan Regency at the PKK of each Village which was carried out from April to August 2020. Respondents consisted of 36 respondents from the PKK and 12 respondents from Kelian Dinas Banjar from the PKK. This research is a descriptive study that uses a strategic management approach, combining SWOT and AHP analysis for the best strategic decision making. The results of the research obtained are internal conditions in the development of PKK creative economic activities in Tabanan City, where the main strength factor is a solid group institution. The main weakness factors are lack of information on getting training activities and limitations in obtaining capital. Furthermore, external conditions in the development of PKK creative economic activities in Tabanan City, where the opportunity factor is good, namely the PKK group has a good image in the village government. For a major threat factor, namely the ease of duplicating products by competitors. So that we get the best strategy that can be applied in the development of PKK creative economic activities in Tabanan City, namely increasing the workforce of distributors to increase sales, in which product marketing requires product affordability to be well accepted by consumers.

Keywords: AHP; strategic management approach; SWOT.

\section{PENDAHULUAN}

Indonesia saat ini merupakan negara berkembang karena sebagian besar penduduk Indonesia berada pada wilayah perdesaan, sehingga pembangunan nasional memiliki tujuan meningkatkan pendapatan dan mensejahterakan rakyat, sehingga kawasan perdesaan harus mendapatkan prioritas utama sebagai perbaikan pembangunan. Kemiskinan menjadi identik didaerah perdesaan, hal ini dapat dilihat dari sebagian besar masyarakat yang berada di perdesaan belum sejahtera. Dengan kehidupan yang penuh keterbatasan dan kemiskinan menjadikan masyarakat diperdesaan tidak berdaya dalam menghadapi cepatnya perkembangan dan perubahan sosial ekonomi dan teknologi. Masyarakat yang tidak berdaya tersebut yaitu masyarakat miskin dimana masalah ekonomi menjadi penyebabnya serta akses informasi dalam memperoleh peningkatan skill dan keterampilan yang kurang didapatkan oleh masyarakat tersebut (Kusumanigrat, 2009). Pada era ekonomi baru memunculkan konsep ekonomi kreatif dalam mengintensifkan informasi dan kreativitas sebagai faktor utama dari sumber daya manusia untuk memunculkan ide dan pengetahuan yang inovatif. 
Di Provinsi Bali terdapat salah satu Kabupaten yang memiliki penduduk yang sebagian besar berada di kawasan perdesaan yaitu Kabupaten Tabanan. Luas wilayah Kabupaten Tabanan adalah $839,33 \mathrm{~km}^{2}$. Khususnya Kecamatan Tabanan merupakan pusat pemerintahan di Kabupaten tabanan yang terdiri dari 12 Desa. Jumlah penduduk sebanyak 73.443 jiwa merupakan kedua terbanyak di Kabupaten Tabanan (Badan Pusat Statistik Kabupaten Tabanan, 2020). Peningkatan jumlah penduduk tentunya sangat berdampak dengan pendapatan masyarakat yang akan dihasilkan, tetapi pemerintah belum mampu dalam penyediaan lapangan kerja yang sesuai. Hal ini mengakibatnya daya beli masyarakat yang ada tidak maksimal dan terjadi penurunan kualitas hidup, khususnya pada permasalahan pendapatan masyarakat kota. Dukungan masyarakat setempat dapat membantu pemerintah dalam mengurangi permasalahan tersebut dengan menciptakan ekonomi kreatif yang ada di Kabupaten Tabanan khususnya Kecamatan Tabanan.

PKK yang mempunyai tugas mengumpulkan anggota anggota masyarakat dari yang paling bawah diharapkan dapat meningkatkan kesejahteraan keluarga sehingga keluarga dapat memenuhi kebutuhan manusia baik secara materi maupun kehidupan sosial agar keluarga dapat hidup sejahtera. Peranan wanita sebagai ibu rumah tangga mulai berubah sejak era globalisasi, dimana wanita saat ini secara langsung juga turut dalam membantu mencukupi kebutuhan rumah tangga. Tenaga kerja wanita memiliki produktivitas yang berperan dan berpotensi dalam mendukung peningkatan pendapatan rumah tangga di pedesaan. Untuk melakukan pembinaan terhadap produktivitas wanita, diperlukan suatu wadah berupa PKK yang dapat dimanfaatkan oleh wanita. Kegiatan PKK yang dilaksanakan di Kota Tabanan selama ini hanya sebatas kegiatan arisan, simpan pinjam dan pelatihan kegiatan wirausaha wanita. Dari hasil pelatihan kegiatan wirausaha tersebut, hanya beberapa PKK yang mampu memanfaatkan pelatihan tersebut menjadi kegiatan ekonomi yang memberikan nilai tambah bagi pendapatan anggotanya. Faktor-faktor penghambat tersebut perlu untuk diminimalisasi agar tidak menjadi penghalang bagi anggota PKK dalam melaksanakan kegiatan ekonomi. Banyak faktor yang dapat mempengaruhi minat wirausaha kelompok wanita seperti: tenaga kerja, skill, lahan, dan jiwa kewirausahaan. Disebutkan dalam penelitian Muljaningsih et al. (2012), modal tidak berpengaruh nyata terhadap minat wirausaha. Hal ini menjadi perhatian dimana selain modal, masih terdapat faktor lainnya yang menjadi penghambat dalam menggerakkan kegiatan ekonomi kreatif kelompok wanita. Manajemen yang baik dalam organisasi PKK dapat memberikan strategi untuk meningkatkan pendapatan anggotanya.

Pengembangan suatu organisasi dipengaruhi oleh manajemen dalam organisasi. Organisasi berperan dalam menentukan strategi dalam mengelola organisasinya. Sasaran-sasaran kerja yang menjadi tujuan organisasi dilakukan berdasarkan landasan yang telah ditentukan untuk menjalankan strategi pengembangan. Sehingga diperlukan penilaian untuk mengukur kekuatan dan kelemahan dalam suatu organisasi yang dapat digunakan untuk perbaikan organisasi pada masa yang akan datang. Hal tersebut diperlukan untuk menghadapi dinamika organisasi yang semakin kompleks. Belum adanya strategi dalam pengembangan PKK di Kota Tabanan menjadikan PKK tidak dapat berkembang dan memberikan nilai ekonomi yang bermanfaat bagi anggotanya. Dari permasalahan tersebut, maka tujuan dari penelitian ini adalah untuk mengidentifikasi kondisi internal dan eksternal dari PKK di Kota Tabanan, serta memilih strategi terbaik yang dapat digunakan PKK di Kota Tabanan dalam pengembangan kegiatan ekonomi kreatif terhadap peningkatan pendapatan anggota.

\section{MATERI DAN METODE}

Lokasi dari penelitian ini dilakukan di Kecamatan Tabanan, Kabupaten Tabanan pada PKK di Masing-masing Desa di Kecamatan Tabanan. Pemilihan PKK ini dilakukan secara sengaja (purposive), peneliti memilih PKK ini dengan pertimbangan PKK di Kecamatan Tabanan merupakan PKK yang berada di pusat pemerintahan Kabupaten Tabanan dan berdasarkan potensi daerah yang dimiliki merupakan daerah penyangga kegiatan pariwisata. Waktu penelitian dilaksanakan pada bulan April sampai Agustus Tahun 2020. Penelitian ini mengambil 12 PKK yang ada di Kecamatan Tabanan dengan 48 responden terdiri dari 36 responden berasal dari PKK dan 12 responden dari Kelian Dinas Banjar dari PKK tersebut. Pemilihan responden penelitian ini dilakukan dengan metode purposive sampling, pertimbangan dalam penggunaan teknik ini dikarenakan responden yang dipilih merupakan subyek pelaku yang direkomendasikan oleh Kepala Desa dengan pertimbangan telah melakukan kegiatan ekonomi kreatif PKK dan mengetahui administrasi lingkungan di Kota Tabanan

Analisa data penelitian ini merupakan penelitian deskriptif yang menggunakan pendekatan manajemen strategi. Alternatif strategi yang dirumuskan dalam mengembangkan kegiatan ekonomi kreatif PKK di Kecamatan Tabanan terhadap peningkatan pendapatan anggota dilakukan dengan menggunakan matriks. Tahapan proses yang dilakukan dalam perumusan alternative strategi yang akan dipilih yaitu: 1) Tahap pengumpulan data dengan menggunakan matriks Internal Factor 
Evaluation (IFE) dan External Factor Evaluation (EFE); 2) Tahap analisis dengan menggunakan matriks Internal External (IE) dan matriks Strength, Weakness, Opportunities, and Threats (SWOT); dan 3) Tahap pengambilan keputusan (Rangkuti, 2015).

Keputusan terbaik dipilih dengan menggunakan Analytic Hierarchy Process (AHP). Menurut Saaty (2008), AHP adalah suatu metode dalam pemilihan keputusan terbaik menggunakan pengukuran beberapa faktor. Faktor-faktor dalam pengukuran untuk pemilihan keputusan tersebut dipergunakan karena tidak semua faktor memiliki sifat tangible. Model AHP merupakan model yang didasarkan pada tujuan (hirarki 1), kriteria atau faktor-faktor yang perlu dipertimbangkan (hirarki ke 2), serta alternatif keputusan (hirarki 3). Kombinasi penggunaan SWOT dan AHP menjadikan hirarki ke-2 diganti dengan komponen SWOT.

\section{HASIL DAN PEMBAHASAN}

\section{Karakteristik PKK Kota Tabanan}

Kota Tabanan yang memiliki daerah cakupan di Kecamatan Tabanan Kabupaten Tabanan termasuk dalam jalur nasional Denpasar Gilimanuk sekitar $24 \mathrm{~km}$ dari Denpasar yang memiliki posisi yang sangat strategis. Dengan posisi yang strategis ini maka Kota Tabanan sangat potensial untuk dikembangkan sebagai daerah ekonomi kreatif yaitu daerah yang melakukan kegiatan produksi berupa komoditas produk lokal menjadi produk yang siap digunakan atau dikonsumsi melalui pembinaan kelompok-kelompok usaha pada bermacam jenis industri rumah tangga (IRT) yang tergabung dalam anggota PKK daerah tersebut. PKK dijadikan sebagai tempat berkumpul dan bekerjasama untuk perempuan di Kota Tabanan dalam pengolahan produk sehingga dapat memberikan hasil yang lebih optimal bagi keluarga dan masyarakat didaerahnya. Anggota PKK diharapkan dapat membuat produk-produk ekonomi kreatif lokal menjadi produk unggulan daerahnya, sehingga dapat meningkatkan kemampuan ekonomi anggota PKK khususnya dan secara umum meningkatkan ekonomi masyarakat Kota Tabanan.

Karakteristik responden dilihat dari kriteria umur dan tingkat pendidikan, maka dapat digambarkan distribusinya seperti pada Tabel 1 . Hasil penelitian menunjukkan seluruh responden berumur antara $17-64$ Tahun sebanyak 48 orang atau 100\%. Hasil tersebut menunjukkan bahwa secara umum responden berada pada kelompok usia masih produktif, dimana usia ini memiliki kemampuan dalam melakukan kegiatan PKK lebih baik lagi karena tenaga yang dimiliki masih berpotensi dan dapat meningkatkan kinerja dalam organisasi kelompok PKK. Selain itu juga usia yang masih produktif akan memberikan semangat jiwa berwirausaha yang dapat meningkatkan pendapatan anggota (Suparyana et al., 2020). Penelitian yang dilakukan oleh Kristiansen et al. (2003) menemukan bahwa terdapat korelasi antara umur dengan kesuksesan bisnis. Usia wirausahawan diatas 25 tahun diketahui lebih sukses jika dibandingkan dengan wirausahawan yang berusia dibawah 25 tahun. Pada usia produktif ini wirausahawan memiliki semangat yang tinggi untuk mengembangkan usaha, memiliki target-target yang tinggi untuk menuju sukses (Indarto \& Santoso, 2020).

Tabel 1. Distribusi Frekuensi Umur dan Tingkat Pendidikan Responden

\begin{tabular}{|c|c|c|c|c|}
\hline No & Kategori & Uraian & Frekuensi & Persentase (\%) \\
\hline \multirow[t]{4}{*}{1} & & $<17$ & - & - \\
\hline & Umur (Th) & $17-64$ & 48 & 100 \\
\hline & & $>64$ & - & - \\
\hline & & Jumlah & 48 & 100 \\
\hline \multirow[t]{6}{*}{2} & & Tidak Sekolah & - & \\
\hline & & SD & 6 & 12,50 \\
\hline & Tingkat Pendidikan & SMP & 5 & 10,42 \\
\hline & & SMA/SMK & 26 & 54,17 \\
\hline & & Diploma/Sarjana & 11 & 22,92 \\
\hline & & Jumlah & 48 & 100 \\
\hline
\end{tabular}

Sumber: Data primer diolah, 2020

Hasil tabulasi data penelitian dapat dilihat bahwa tingkat pendidikan SMA/SMK merupakan pendidikan responden terbanyak yaitu sebanyak 26 orang atau $54,17 \%$. Hasil penelitian diketahui cukup memadainya tingkat pendidikan responden dalam menjalankan kegiatan program kerja PKK dan tidak menjadikan hambatan bagi PKK untuk berinovasi dalam meningkatkan produk kelompok PKK. Tingkat pendidikan dapat digunakan tolak ukur dari kemampuan dan pengetahuan seseorang. Hal ini berkaitan dengan semakin tingginya tingkat pendidikan yang telah dicapai, maka perhatiannya 
akan lebih detail terhadap manajemen usahanya (Suparyana et al., 2020). Dalam penelitian Utari \& Dewi (2014) dan Istinganah \& Widiyanto (2020), mengemukakan bahwa tingkat pendidikan secara simultan berpengaruh signifikan terhadap pendapatan suatu usaha. Semakin tinggi tingkat pendidikan maka semakin tinggi tingkat pendapatan yang diterima usaha tersebut. Dengan tingkat pendidikan yang memadai akan memberikan kemampuan dalam mengelola manajemen usaha yang dapat meningkatkan pendapatan usaha tersebut.

Aneka ragam produk PKK masing-masing Desa di Kecamatan Tabanan sangat bervariasi, produk PKK tersebut ditunjukkan pada Tabel 2. Pada Tabel 2 tersebut menunjukkan produk ekonomi kreatif anggota PKK di Kecamatan Tabanan sebagian besar berupa Produk kue, jajan upakara dan sarana upakara. Hal ini dilihat dari permintaan konsumen yang banyak digunakan untuk sarana persembahyangan di setiap desa. Selain itu produk tersebut dapat disimpan dalam jangka waktu lebih lama, sehingga dapat dijadikan stok dalam jangka waktu tertentu apabila memiliki kelebihan produk. Dalam penelitian Marwanti \& Astuti (2012) mengemukakan komponen dalam pemberdayaan perempuan yang dapat dilaksanakan dengan capacity building agar produk yang dihasilkan menarik bagi pembeli dan sesuai selera pasar dan memperhitungkan potensi pasar. Dengan adanya permintaan konsumen perlu dilakukan diversifikasi pada produk yang telah diproduksi oleh PKK untuk memberikan kepuasan bagi konsumen. Hal ini sejalan dengan penelitian Khamidi (2013) dan Sa'adah (2020) menyatakan bahwa diversifikasi produk berpengaruh signifikan terhadap kepuasan pelanggan yang berdampak pada peningkatan penjualan.

Tabel 2. Produk PKK

\begin{tabular}{cll}
\hline No & \multicolumn{1}{c}{ Desa } & \multicolumn{1}{c}{ Produk } \\
\hline 1 & Desa Bongan & Jajan Upakara \\
2 & Desa Sudimara & Krupuk, Kue, Ikan Pindang, Jaja Bali \\
3 & Desa Tunjuk & Jajan Upakara, Sarana Upakara, Tamas, Bantal, Tape \\
4 & Desa Dajan Peken & Kue; sarana upakara; Lauk-pauk; nasi kotak; kerajinan tangan \\
5 & Desa Denbantas & Abon; dupa; jajan upakara \\
6 & Desa Wanasari & Jajan bali; pot bunga \\
7 & Desa Buahan & Minyak Kelapa \\
8 & Desa Dauh Peken & Jajan Upakara \\
9 & Desa Delod Peken & Kue Basah \\
10 & Desa Subamia & Sarana Upakara \\
11 & Desa Gubug & Kue, Sarana Upakara \\
12 & Desa Sesandan & Jajan bali \\
\hline
\end{tabular}

Sumber: Data primer diolah, 2020

\section{Matriks IFE dan EFE}

Hasil perhitungan faktor internal strategi pengembangan PKK ditunjukkan pada Tabel 3. Berdasarkan Tabel IFE, bahwa faktor kekuatan yang diharapkan dapat meminimalkan faktor kelemahan dalam pengembangan PKK yaitu dengan Kelembagaan kelompok yang solid. Situasi kerjasama dalam kelompok menyebabkan tiap orang mempercayai dan memiliki rasa nyaman serta dapat berkomunikasi secara efektif dan merespons dengan saling membantu keinginan, kebutuhan, dan permintaan (Jamiatun et al., 2018; Johnson et al., 2012). Sejalan dengan penelitian Sugitarina et al. (2016) mengemukakan keberhasilan suatu program dalam kelompok dapat dilihat dari aspek sosial yaitu kekompakan kelompok. Dengan adanya kerjasama yang solid akan memberikan kekuatan bagi kelompok untuk terus berkembang dalam memajukan kelompoknya. Dengan adanya faktor kekuatan tersebut diharapkan dapat meminimalkan kelemahan terbesar yang dihadapi dalam pengembangan PKK yaitu Kurangnya informasi mendapatkan kegiatan pelatihan dan Keterbatasan memperoleh modal. Untuk menanggulangi kelemahan tersebut perlu dilakukan koordinasi agar informasi pelatihan dapat diberikan kepada anggota PKK dan akses modal diperluas kepada anggota PKK.

Tabel 3. Matriks IFE

\begin{tabular}{clccc}
\hline No & Faktor-faktor Strategi Internal & Bobot & Rating & B $\times$ R \\
\hline A & Kekuatan: & & & \\
1 & Kelembagaan kelompok yang solid & 0,10 & 3,15 & 0,31 \\
2 & Ketersediaan bahan baku yang mudah & 0,11 & 2,77 & 0,30 \\
3 & Pemasaran dengan media online & 0,10 & 2,52 & 0,25 \\
4 & Budaya organisasi yang kondusif & 0,10 & 2,75 & 0,28 \\
5 & Rutinitas kegiatan pertemuan kelompok & 0,10 & 3,00 & 0,30 \\
\hline
\end{tabular}


Tabel 3. Matriks IFE

\begin{tabular}{ccccc}
\hline No & Faktor-faktor Strategi Internal & Bobot & Rating & B x R \\
\hline B & Kelemahan: & & & \\
1 & Kurangnya informasi mendapatkan kegiatan pelatihan & 0,10 & 2,88 & 0,29 \\
2 & Keterbatasan peralatan produksi & 0,10 & 2,58 & 0,26 \\
3 & Keterbatasan teknologi produksi & 0,10 & 2,79 & 0,28 \\
4 & Keterbatasan memperoleh modal & 0,11 & 2,63 & 0,29 \\
5 & Produk masih bersifat tradisional & 0,08 & 2,58 & 0,21 \\
\hline & Total & 1,00 & & 2,77 \\
\hline
\end{tabular}

Sumber: Data primer diolah, 2020

Hasil perhitungan faktor eksternal strategi pengembangan PKK dapat dilihat pada Tabel 4. Berdasarkan Tabel EFE, bahwa faktor peluang yang terbaik dalam pengembangan PKK yaitu Kelompok PKK memiliki citra yang baik di pemerintahan desa. Citra baik ini akan memberikan akses pemasaran pada produk yang dihasilkan anggota PKK dan memberikan peluang dalam pembinaan yang berkelanjutan dari pemerintah desa. Peluang ini harus tetap dijaga dengan memberikan citra yang baik dalam pengelolaan manajemen PKK. Unsur terpenting dalam modal sosial adalah kepercayaan yang merupakan perekat bagi langgengnya kerjasama dalam kelompok masyarakat (Anisa et al., 2020; Fukuyama, 2001; Roslinda et al., 2017; Susanti et al., 2018; Wuysang, 2014). Dengan adanya citra yang baik, maka akan memunculkan rasa kepercayaan orang-orang untuk dapat bekerjasama secara lebih efektif. Sehingga pemerintah desa akan lebih percaya dalam memberikan program-program kegiatan kepada kelompok tersebut. Dengan adanya peluang tersebut dapat meminimalisasi ancaman yang akan timbul. Faktor ancaman yang besar dalam pengembangan kegiatan ekonomi kreatif PKK di Kota Tabanan yaitu kemudahan dalam duplikasi produk oleh pesaing. Selain dengan memberikan citra yang baik, untuk menanggulangi hal tersebut diperlukan juga suatu pengembangan produk, sehingga produk ekonomi kreatif anggota PKK dapat bersaing dipasaran.

Tabel 4. Matriks EFE

\begin{tabular}{|c|c|c|c|c|}
\hline No & Faktor-faktor Strategi Eksternal & Bobot & Rating & $B \times R$ \\
\hline \multicolumn{5}{|c|}{ Peluang: } \\
\hline 1 & Kelompok PKK memiliki citra yang baik di pemerintahan desa & 0,10 & 3,33 & 0,33 \\
\hline 2 & Kegiatan pelatihan yang diberikan memiliki unsur inovatif & 0,10 & 2,88 & 0,29 \\
\hline 3 & $\begin{array}{l}\text { Kegiatan pelatihan yang diberikan memiliki unsur kreatif } \\
\text { Perhatian dari dinas, instansi, dan kampus terhadap kelompok }\end{array}$ & 0,10 & 2,67 & 0,27 \\
\hline 4 & tinggi & 0,10 & 2,88 & 0,29 \\
\hline 5 & SDM aktif dalam kegiatan wirausaha & 0,10 & 2,98 & 0,30 \\
\hline \multicolumn{5}{|c|}{ Ancaman: } \\
\hline 1 & Kemudahan dalam duplikasi produk oleh pesaing & 0,10 & 2,56 & 0,26 \\
\hline 2 & Munculnya pesaing usaha & 0,10 & 2,25 & 0,23 \\
\hline 3 & Harga bahan baku tidak stabil & 0,10 & 2,23 & 0,22 \\
\hline 4 & Keterbatasan waktu dengan kegiatan adat & 0,10 & 1,98 & 0,20 \\
\hline 5 & Perubahan selera konsumen & 0,10 & 2,02 & 0,20 \\
\hline & Total & 1,00 & & 2,58 \\
\hline
\end{tabular}

Sumber: Data primer diolah, 2020

\section{Matriks IE}

Fungsi dari penggunaan Matriks IE dipergunakan untuk mengetahui posisi saat ini PKK. Pemilihan strategi sangat ditentukan oleh pemetaan posisi PKK. Berdasarkan analisis matriks IFE diperoleh total skor 2,77 dan total skor EFE yaitu sebesar 2,58. Matriks IE dapat dilihat pada Gambar 1. Dari matriks IFE dan EFE selanjutnya disatukan menjadi matriks IE. Hasil tersebut menunjukkan PKK pada posisi sel V. Strategi yang dapat dijadikan acuan pada sel V ini adalah strategi mempertahankan dan pemeliharaan (hold and maintain). Strategi penetrasi pasar serta pengembangan produk adalah strategi yang paling cocok digunakan pada posisi ini (David, 2004). Peningkatan pangsa pasar (market share) merupakan strategi penetrasi pasar dengan melakukan pemasaran yang gencar pada produk atau jasa yang telah ada di pasaran. Peningkatan dan modifikasi produk-produk yang sudah ada merupakan strategi pengembangan produk sehingga dapat meningkatkan penjualan. 


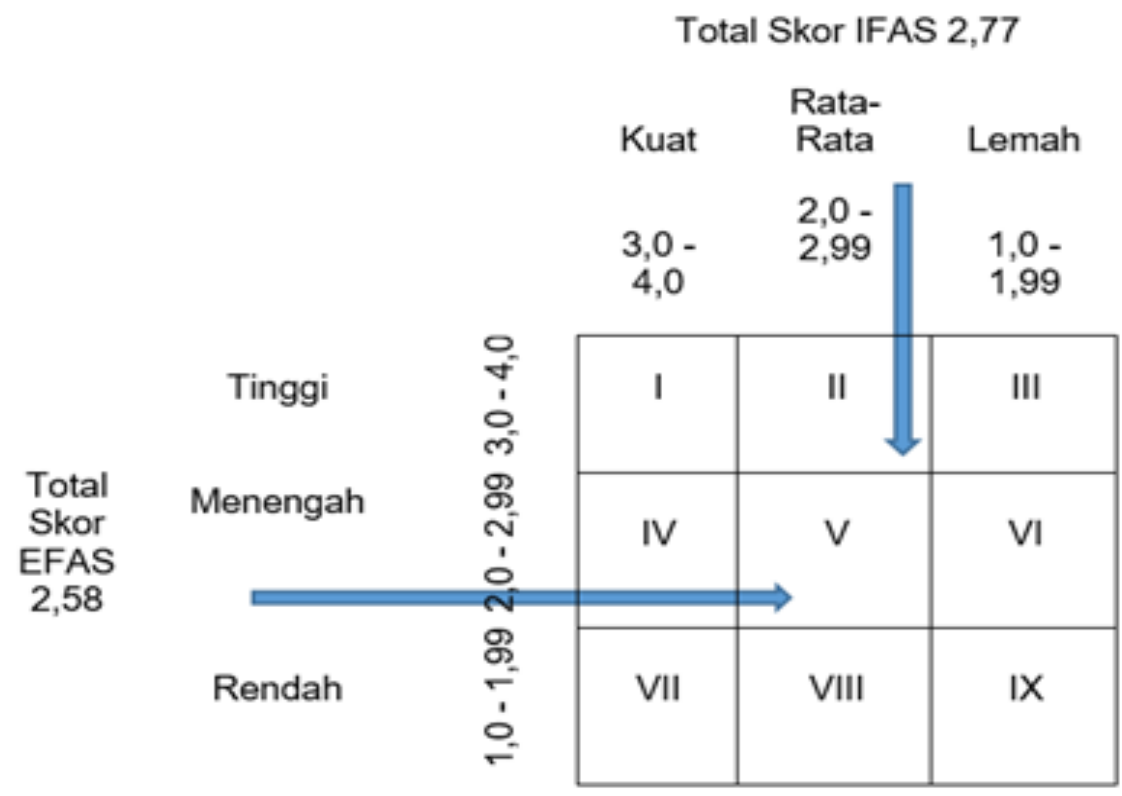

Gambar 1. Matriks IE

Penetrasi pasar terdiri dari peningkatkan jumlah tenaga penjual, memberikan promosi penjualan yang ekstensif serta meningkatkan publisitas usaha (Suparyana et al., 2020). Untuk meningkatkan pangsa pasar produk ekonomi kreatif anggota PKK, PKK dapat melakukan strategi dengan membuat pelanggan berkeinginan dalam membeli produk lebih banyak dari biasanya maupun menambah jumlah tenaga penjual (distributor). Strategi tersebut dapat dilaksanakan dengan promosi penjualan melalui media sosial atau memberikan promosi penjualan ekstensif, misalnya dengan menambahkan bonus produk untuk pembelian dalam jumlah yang banyak. Pelayanan yang lebih baik dapat dijadikan strategi lainnya, seperti kontinyuitas ketersediaan produk, konsistensi kualitas produk, ketepatan waktu dalam pengiriman dan kesesuaian pesanan, serta memberikan keramah-tamahan kepada pelanggan yang berbelanja.

Strategi pengembangan produk adalah strategi dalam meningkatkan penjualan dengan cara menambahkan dan memodifikasi produk-produk atau jasa yang sudah ada (David, 2004). Tujuan dari dilakukannya strategi pengembangan produk adalah peningkatan daya saing usaha. Perluasan lini produk yang dijual merupakan diferensisasi produk dari segi bentuk, kualitas dan variasi kemasan. Hal tersebut dapat memberikan dampak untuk kepuasan konsumen akan meningkat dengan semakin banyaknya pilihan produk yang ditawarkan (Suparyana et al., 2020).

\section{Matriks SWOT}

Matriks SWOT dapat memberikan gambaran terhadap manajemen dalam pencocokan kekuatan dan kelemahan internal PKK dengan peluang-peluang dan ancaman-ancaman eksternal yang dihadapi PKK. Dalam menghasilkan alternatif strategi yang baik, perlu dilakukan tahap pencocokan (matriks SWOT). Tahap ini bukan untuk memilih strategi terbaik, tetapi hanya untuk menghasilkan strategi yang layak digunakan. Hal tersebut dilakukan untuk memilih implementasi strategi prioritas dari beberapa strategi yang dikembangkan dalam matriks SWOT. Staretgi prioritas yang dapat disarankan sebagai berikut: strategi SO (Strengths-Opportunities), WO (WeaknessOpportunities), ST (Strengths-Threats) dan WT (Weakness- Threats). Data yang digunakan dalam analisis ini diperoleh dari matriks IFE dan EFE. Tabel 5 menunjukkan hasil analisis matriks SWOT pengembangan kegiatan ekonomi kreatif PKK di Kota Tabanan.

Berdasarkan Tabel 5, strategi S-O merupakan strategi yang menjadikan kekuatan internal dalam PKK untuk memanfaatkan peluang eksternal sehingga dapat memperoleh keuntungan bagi PKK. Strategi alternatif yang dapat dilaksanakan pada strategi S-O adalah memberikan pelatihan dan penyuluhan kegiatan ekonomi kreatif. Jika dilihat dari penelitian Susatin (2019), indikator peningkatan kualitas sumber daya manusia dalam mengembangkan keterampilan kelompok PKK untuk memberikan solusi permasalahan yang ada pada kegiatan Program Kerja PKK dapat dilakukan dengan cara melaksanakan pendidikan. Pelaksanaan pendidikan dapat dilakukan dengan memberikan diklat terkait program PKK, yang memiliki tujuan dalam peningkatan pengetahuan yang lebih luas mengenai pentingnya suatu program PKK yang dijalankan. 
Tabel 5. Matriks SWOT

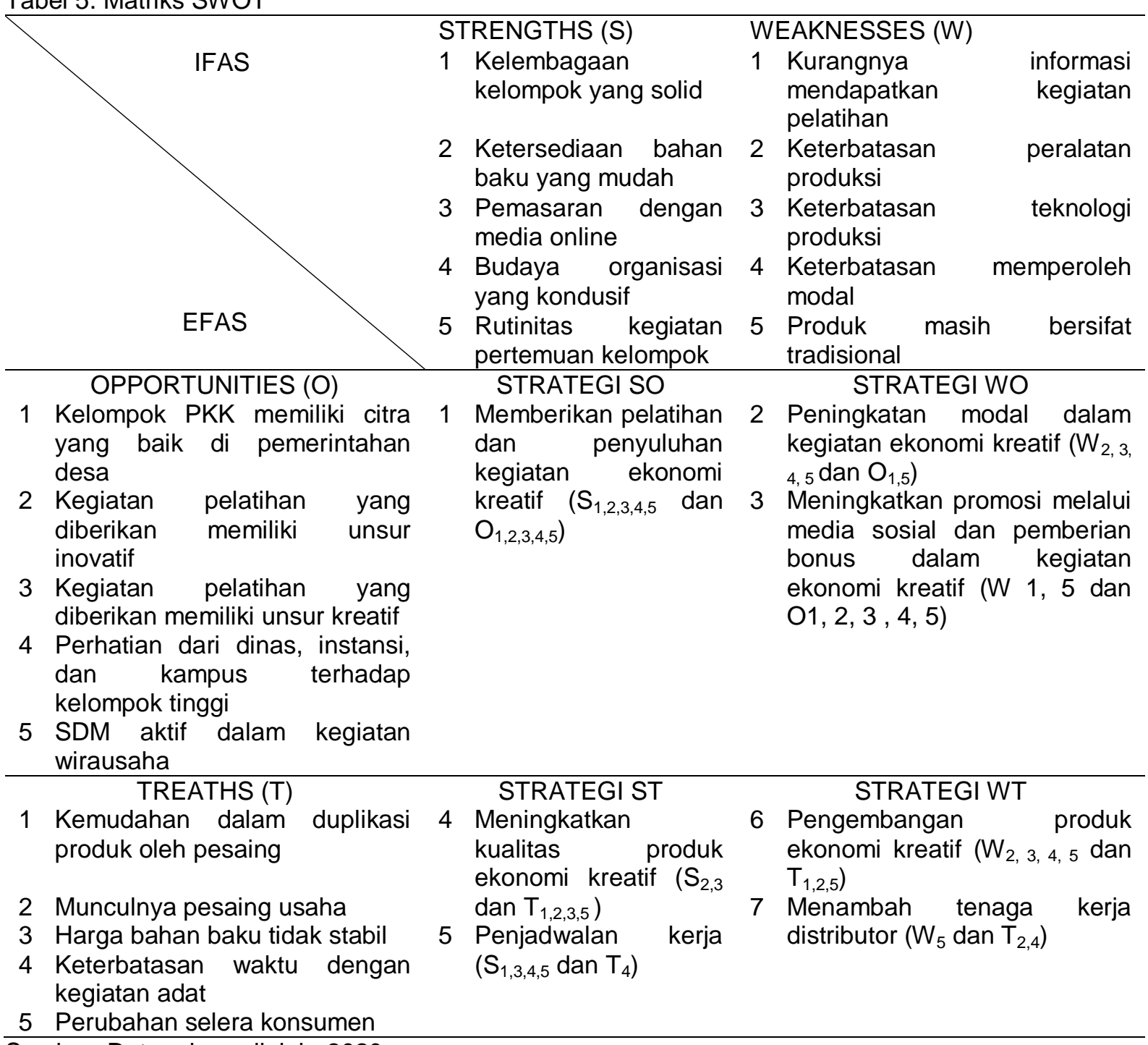

Sumber: Data primer diolah, 2020

Strategi W-O merupakan strategi yang memiliki tujuan untuk mengatasi kelemahan internal yag ada dengan memanfaatkan peluang eksternal PKK. Terdapat dua strategi alternatif yang dapat dilaksanakan pada strategi W-O, yaitu:

1. Peningkatan modal dalam kegiatan ekonomi kreatif

Keterbatasan modal dapat menjadi faktor penghambat dalam mengembangkan usaha. Anggota PKK dapat menambah modal dengan pihak lembaga keuangan dan Dinas Koperasi, contohnya melalui pengajuan proposal kepada lembaga keuangan tersebut bahwa produk yang diproduksi memiliki keberagaman dan keunikan. Dengan adanya perkembangan informasi, hal tersebut akan membantu dalam mencari informasi di internet terkait permodalan. Selain itu, dukungan Dinas yang membidangi Pemberdayaan Perempuan dan Dinas Koperasi Kota Tabanan juga dapat dimaksimalkan, karena Dinas terkait memiliki fungsi sebagai penyedia fasilitas dalam mendapatkan informasi terkait permodalan kepada pihak lembaga keuangan ataupun BUMN. Karena pihak tersebut dapat melakukan kerjasama untuk mengadakan sosialisasi terkait permodalan untuk UKM melalui Dinas terkait. Apabila modal meningkat, maka usaha anggota PKK dapat memenuhi permintaan pelanggan terhadap produk dan memperluas pemasarannya. Dalam penelitian pengaruh modal terhadap pertumbuhan usaha (Endang Purwanti, 2012; Safitri \& Setiaji, 2018), didapatkan hasil yang berpengaruh nyata dikarenakan modal sebagai pendukung dalam menjalankan usaha dalam menyediakan input yang digunakan dalam produksi

2. Meningkatkan promosi melalui media sosial dan pemberian bonus dalam kegiatan ekonomi kreatif. 
Usaha ekonomi kreatif anggota PKK dapat lebih mengoptimalkan media sosial sebagai promosi yang telah banyak dimanfaatkan oleh netizen saat ini. Promosi juga bisa dilakukan dengan kerjasama pada kawasan wisata atau outlet di pasar dengan membawa tester produk yang ditawarkan kepada wisatawan dan pemilik outlet yang berada di jalan besar. Pembuatan website resmi khusus produk PKK dapat digunakan sebagai media promosi tambahan produk ekonomi kreatif anggota PKK. Promosi lainnya dapat dilakukan dengan menawarkan produk melalui kegiatan-kegiatan, seperti seminar, kegiatan pelatihan dan kegiatan adat serta pernikahan. Selanjutnya, anggota PKK dapat lebih mengoptimalkan promosi melalui penitipan produknya di pasar modern dan tradisional yang terdapat di Kota Tabanan. Keseluruhan promosi tersebut dilakukan secara gencar, dan memberikan bonus jika membeli dalam jumlah yang banyak. Dengan memaksimalkan promosi, maka produk yang diproduksi oleh anggota PKK akan dikenal secara luas oleh masyarakat. Strategi ini sejalan dengan penelitian yang dilakukan pada media sosial yang digunakan untuk mempromosikan produk sehingga dapat memberi peningkatan penjualan (Indika \& Jovita, 2017; Indrawati et al., 2017; Reinhart Abedneju Sondakh et al., 2019; Setiawan et al., 2019; Untari \& Fajariana, 2018).

Strategi S-T ini menggunakan kekuatan internal PKK untuk mengurangi dan menghindari pengaruh dari ancaman eksternal PKK. Terdapat dua strategi alternatif yang dapat dilakukan pada strategi S-T yaitu:

1. Meningkatkan kualitas produk ekonomi kreatif

Meningkatkan kualitas produk dapat membuat pelanggan akan selalu tertarik dengan produk yang diberikan oleh anggota PKK, meskipun terdapat pesaing yang menawarkan produk sejenis. Dengan kualitas yang dipertahankan, loyalitas konsumen terhadap produk yang diberikan akan selalu terjaga. Selain itu, didukung dengan adanya rekanan yang baik dengan pelanggan, sehingga dapat memberikan dampak positif bagi PKK. Dampak tersebut membuat para pelanggan akan selalu setia dengan produk yang dijual. Kualitas produk anggota PKK ditentukan oleh bahan baku yang digunakan dan proses yang dikerjakan dengan baik. Oleh karena itu, anggota PKK harus selalu konsisten dengan penggunaan bahan baku dan proses yang standar agar kualitas produk yang dihasilkan tetap terjaga dengan baik. Perusahaan dalam bertahan dan berkembang harus mampu mempertahankan serta meningkatkan kualitas produknya sehingga dapat bersaing di pasaran (Purwono et al., 2008).

2. Penjadwalan kerja

Penjadwalan yang baik akan berdampak pada produksi yang dilakukan secara berkelanjutan dan menghasilkan tingkat penjualan yang tinggi apabila dibandingkan dengan produksi yang hanya berdasarkan pesanan saja. Umumnya permasalahan usaha adalah dibidang penjadwalan produksi (Harto et al., 2016; Nasution et al., 2017; Suparyana et al., 2020; D. M. Utama, 2016, 2019), sehingga diperlukan manajemen dalam penjadwalan kerja untuk melaksankan produksi secara kontinyu. Anggota PKK memiliki potensi untuk berproduksi secara kontinyu, hal tersebut didukung dengan adanya perolehan bahan baku dengan mudah.

Strategi W-T merupakan strategi yang diarahkan pada pengurangan kelemahan internal dan menghindari ancaman eksternal. Terdapat dua alternatif strategi yang dapat dilakukan pada strategi W-T yaitu:

1. Pengembangan produk ekonomi kreatif

Adanya dukungan dari Dinas yang membidangi pemberdayaan perempuan Kabupaten Tabanan dan Intitusi Perguruan Tinggi sebagai fasilitator bagi PKK, salah satunya yaitu memudahkan dalam memasarkan produk secara online melalui media sosial. Pengembangan produk yang ditawarkan terus ditingkatkan dengan menambahkan jenis dan variasi produk baru, sehingga mampu bersaing dipasaran. Pengembangan produk yang dilakukan anggota PKK dengan memberikan jenis, varian rasa, bentuk maupun kemasan yang baru pada setiap produk. Jenis produk/hiasan baru juga perlu ditambahkan untuk memberikan variasi pilihan kepada konsumen jika sudah mulai terdapat perkembangan karena trend yang muncul. Dengan adanya keberagaman produk yang dikembangkan oleh anggota PKK, diharapkan mampu menarik perhatian dan memberikan pilihan yang beragam bagi konsumen. Inovasi produk ini sangat penting artinya terhadap kebutuhan pelanggan, khususnya dalam kaitannya dengan kegiatan pemasaran yang dilakukan suatu organisasi dalam menghadapi persaingan yang semakin kompetitif (Indriani, 2006; Romli, 2019).

2. Menambah tenaga kerja distributor

Penambahan tenaga kerja distributor dapat memperkuat dan memperluas jaringan distribusi yang sudah ada pada saat ini. Peran distributor sangat penting dalam memasarkan suatu produk (Ishak, 2016; Nurseto, 2018). Dengan adanya distributor yang handal, dapat menyalurkan produk secara maksimal dari produsen sampai ke konsumen dengan baik. Adapun cara yang 
dapat dilakukan PKK dalam meningkatkan jumlah penjualannya yaitu dengan mencari dan bekerjasama dengan tenaga distributor yang ada di lokasi strategis dengan sistem bagi hasil.

\section{Analisis Hirarki Proses \\ Identifikasi Sistem}

Komponen pembentukan sistem prioritas strategi pengembangan kegiatan ekonomi kreatif PKK di Kota Tabanan meliputi penentuan kriteria dan alternatif. Adapun kriteria yang digunakan adalah kriteria kebijakan desa, kelembagaan PKK, Akses Modal, dan Pemasaran Produk. Penentuan kriteria ini ditentukan oleh dasar teori yang ada. Sedangkan untuk alternatif strateginya adalah memberikan pelatihan dan penyuluhan kegiatan ekonomi kreatif, peningkatan modal dalam kegiatan ekonomi kreatif, meningkatkan promosi melalui media sosial dan pemberian bonus dalam kegiatan ekonomi kreatif, meningkatkan kualitas produk ekonomi kreatif, penjadwalan kerja, pengembangan produk ekonomi kreatif, dan menambah tenaga kerja distributor. Alternatif ini terpilih dari hasil analisa SWOT. Jumlah pakar yang terlibat pada penelitian ini adalah sebanyak 9 orang yang terdiri dari praktisi dalam bidang PKK (1 orang), pemerintahan yang diwakilkan dinas terkait bidang pemberdayaan perempuan (3 orang), pakar pemberdayaan perempuan (4 orang) dan pakar industri (1 orang).

\section{Penyusunan hirarki}

Penyusunan prioritas suatu hirarki keputusan dalam pemilihan prioritas strategi pengembangan kegiatan ekonomi kreatif PKK di Kota Tabanan dengan menganalisis seluruh pendapat dari para pakar yang telah dilibatkan dapat dilihat pada Gambar 2.

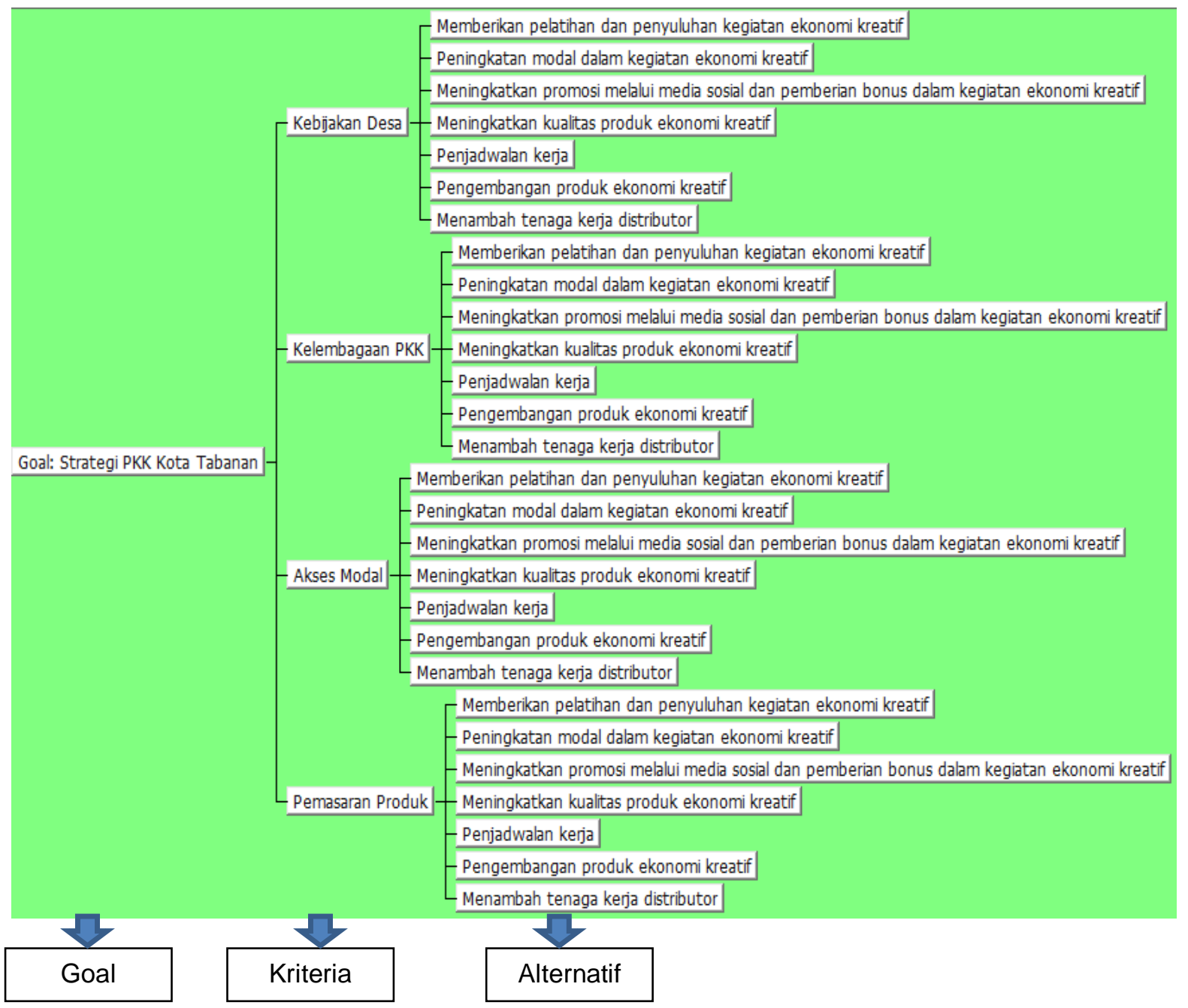

Gambar 2. Struktur hirarki pemilihan prioritas strategi pengembangan kegiatan ekonomi kreatif PKK di Kota Tabanan 


\section{Hasil pengolahan horisontal terhadap sasaran utama (Goal)}

Prioritas pengembangan untuk setiap kriteria ditunjukkan dengan nilai bobot masing-masing kriteria, setiap bobot merupakan ukuran tiap kepentingan suatu kriteria dengan kriteria yang lain pada tingkat keputusan yang sama, pada suatu tingkat hirarki keputusan. Bobot yang dihasilkan dari pengolahan horisontal kriteria terhadap goal merupakan hasil pengolahan bobot kriteria agegasi pakar, urutan prioritas ditunjukkan pada Gambar 3. Hasil analisis menunjukkan bahwa bahwa pemasaran produk yang menjadi prioritas utama dalam membuat strategi pengembangan kegiatan ekonomi kreatif PKK di Kota Tabanan yang memiliki nilai bobot yaitu 0,614 atau $61,4 \%$. Untuk prioritas ke dua ditempati oleh kriteria akses modal dengan bobot 0,247 atau $24,7 \%$, urutan ke tiga ditempati oleh kriteria kelembagaan PKK dengan bobot 0,095 atau 9,5\%, dan kriteria kebijakan desa terakhir dengan bobot 0,043 atau $4,3 \%$.

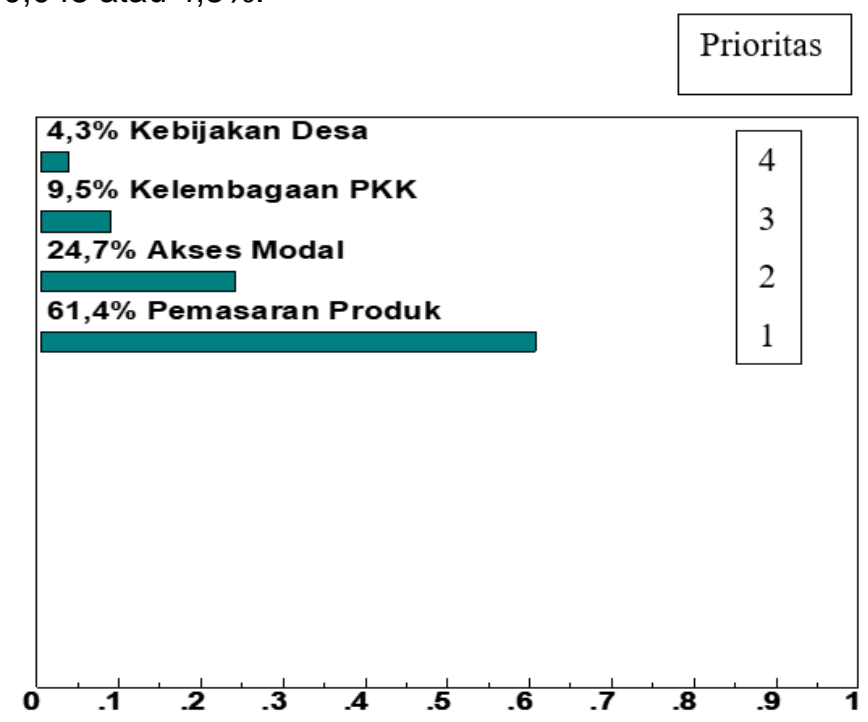

Gambar 3. Prioritas kriteria terhadap goal

Terpilihnya kriteria pemasaran produk menjadi prioritas utama, ini dikarenakan pemasaran produk menjadi kunci utama yaitu produk belum dapat tersalurkan dengan baik, maka dengan permasalahan tersebut perlu adanya kegiatan pemasaran produk yang maksimal sehingga dengan pemasaran yang maksimal akan meningkat penjualan dan dapat meningkatkan pendapatan anggota PKK yang melakukan kegiatan ekonomi kreatif tersebut. Pemasaran yang efektif dan efesien terhadap suatu produk yang ditawakan dapat meningkatkan omset pendapatan (Putriyandari et al., 2018; I. D. Utama, 2019). Persaingan yang semakin kompetitif mengharuskan PKK dapat membuat strategi yang tepat dengan memperhatikan bauran pemasaran, sehingga dapat bersaing di pasar sasaran produknya.

\section{Hasil pengolahan horisontal alternatif terhadap kriteria}

Pengolahan horisontal ini merupakan pengolahan antar alternatif agegasi pakar untuk memperoleh bobot yang baru untuk menentukan prioritas setiap alternatif pada masing masing kriteria. Urutan prioritas alternatif yang dihasilkan ditunjukkan pada Tabel 6.

Tabel 6. Hasil pengolahan horisontal alternatif terhadap kriteria.

\begin{tabular}{|c|c|c|c|c|c|c|c|c|}
\hline \multirow[b]{2}{*}{ Alternatif } & \multicolumn{2}{|c|}{$\begin{array}{l}\text { Kebijakan } \\
\text { Desa }\end{array}$} & \multicolumn{2}{|c|}{$\begin{array}{c}\text { Kelembagaan } \\
\text { PKK }\end{array}$} & \multicolumn{2}{|c|}{ Akses Modal } & \multicolumn{2}{|c|}{$\begin{array}{l}\text { Pemasaran } \\
\text { Produk }\end{array}$} \\
\hline & Bobot & $P$ & Bobot & $P$ & Bobot & $P$ & Bobot & $\mathrm{P}$ \\
\hline $\begin{array}{ll}\text { Memberikan pelatihan dan } \\
\text { penyuluhan } & \text { kegiatan } \\
\text { ekonomi kreatif } & \end{array}$ & 0,023 & 7 & 0,025 & 7 & 0,022 & 7 & 0,020 & 7 \\
\hline $\begin{array}{l}\text { Peningkatan modal dalam } \\
\text { kegiatan ekonomi kreatif }\end{array}$ & 0,037 & 6 & 0,043 & 6 & 0,041 & 6 & 0,037 & 6 \\
\hline $\begin{array}{l}\text { melalui media sosial dan } \\
\text { pemberian bonus dalam } \\
\text { kegiatan ekonomi kreatif }\end{array}$ & 0,064 & 5 & 0,063 & 5 & 0,61 & 5 & 0,070 & 5 \\
\hline
\end{tabular}


Tabel 6. Hasil pengolahan horisontal alternatif terhadap kriteria.

\begin{tabular}{|c|c|c|c|c|c|c|c|c|}
\hline \multirow[b]{2}{*}{ Alternatif } & \multicolumn{2}{|c|}{$\begin{array}{l}\text { Kebijakan } \\
\text { Desa }\end{array}$} & \multicolumn{2}{|c|}{$\begin{array}{l}\text { Kelembagaan } \\
\text { PKK }\end{array}$} & \multicolumn{2}{|c|}{ Akses Modal } & \multicolumn{2}{|c|}{$\begin{array}{l}\text { Pemasaran } \\
\text { Produk }\end{array}$} \\
\hline & Bobot & $\mathrm{P}$ & Bobot & $\mathrm{P}$ & Bobot & $\mathrm{P}$ & Bobot & $\mathrm{P}$ \\
\hline $\begin{array}{ll}\text { Meningkatkan kualitas } \\
\text { produk ekonomi kreatif }\end{array}$ & 0,110 & 4 & 0,111 & 4 & 0,111 & 4 & 0,101 & 4 \\
\hline Penjadwalan kerja & 0,149 & 3 & 0,132 & 3 & 0,153 & 3 & 0,130 & 3 \\
\hline $\begin{array}{l}\text { Pengembangan produk } \\
\text { ekonomi kreatif }\end{array}$ & 0,281 & 2 & 0,267 & 2 & 0,257 & 2 & 0,269 & 2 \\
\hline $\begin{array}{l}\text { Menambah tenaga kerja } \\
\text { distributor }\end{array}$ & 0,336 & 1 & 0,359 & 1 & 0,356 & 1 & 0,373 & 1 \\
\hline
\end{tabular}

Keterangan. P: Prioritas

Sumber: Data primer diolah, 2020

Hasil pengolahan horisontal alternatif terhadap kriteria menunjukkan bahwa alternatif strategi pengembangan kegiatan ekonomi kreatif PKK di Kota Tabanan yang menjadi prioritas berdasarkan kriteria kebijakan desa, kelembagaan PKK, akses modal, dan pemasaran produk adalah Menambah tenaga kerja distributor, kemudian disusul berturut-turut dengan Pengembangan produk ekonomi kreatif, Penjadwalan kerja, Meningkatkan kualitas produk ekonomi kreatif, Meningkatkan promosi melalui media sosial dan pemberian bonus dalam kegiatan ekonomi kreatif, Peningkatan modal dalam kegiatan ekonomi kreatif dan Memberikan pelatihan dan penyuluhan kegiatan ekonomi kreatif. Menambah tenaga kerja distributor menjadi prioritas tertinggi yang berkaitan dengan pemasaran produk ke konsumen secara maksimal yang dapat meningkatkan penjualan. Ishak (2016) dan Nurseto (2018) mengemukakan peran distributor sangat penting dalam memasarkan suatu produk. Dimana distributor memiliki peran dalam menyalurkan produk dari konsumen menuju produsen. Jika distributor tidak memiliki kemampuan yang baik dalam memasarkan suatu produk, maka dapat menurunkan omzet penjualan produk tersebut.

\section{Hasil pengolahan vertikal alternatif terhadap kriteria}

Pengolahan vertikal dilakukan untuk memperoleh tingkat kepentingan setiap alternatif strategi pengembangan kegiatan ekonomi kreatif PKK di Kota Tabanan yang diusulkan. Bobot yang dihasilkan pada pengolahan ini merupakan nilai rata-rata dari setiap bobot alternatif hasil pengolahan horisontal alternatif terhadap kriteria pada tingkat kriteria yang sama. Hasil pengolahan vertikal alternatif terhadap kriteria dapat disajikan pada Gambar 4 dan Gambar 5.

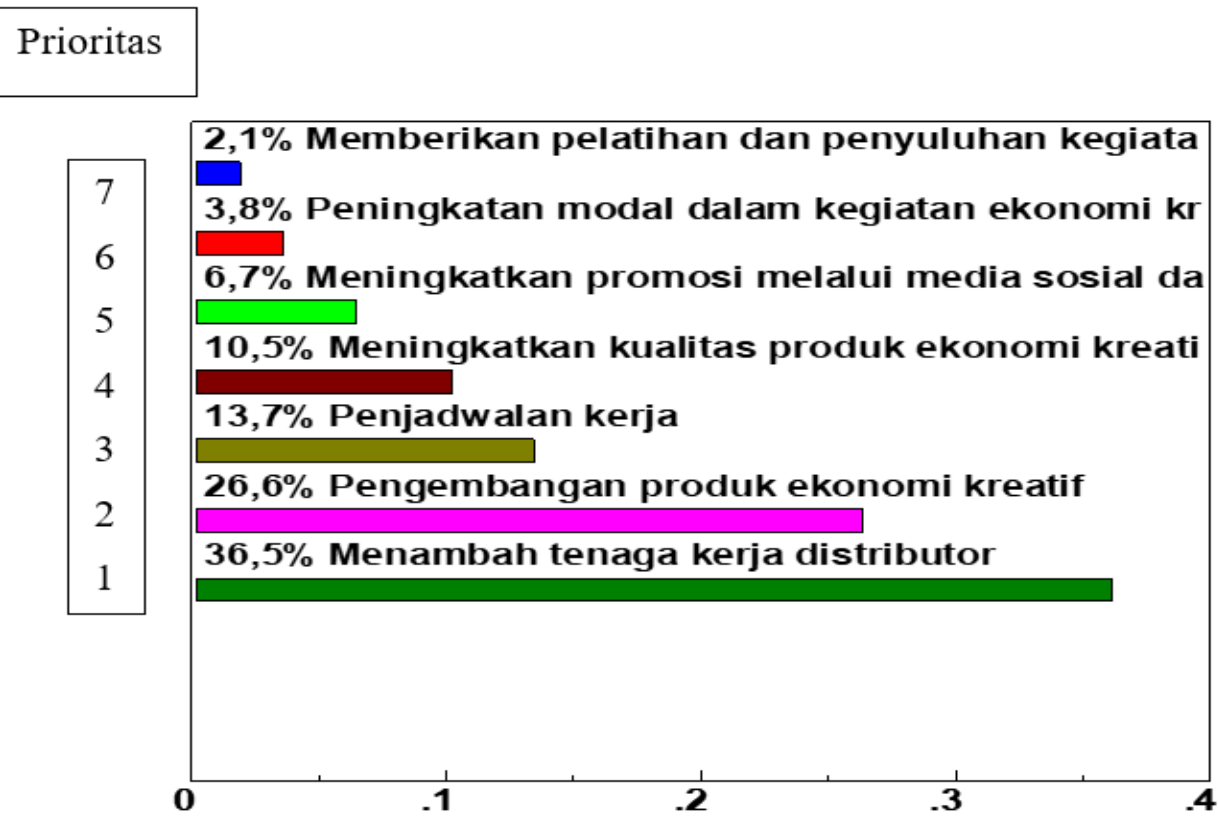

Gambar 4. Prioritas alternatif terhadap kriteria 


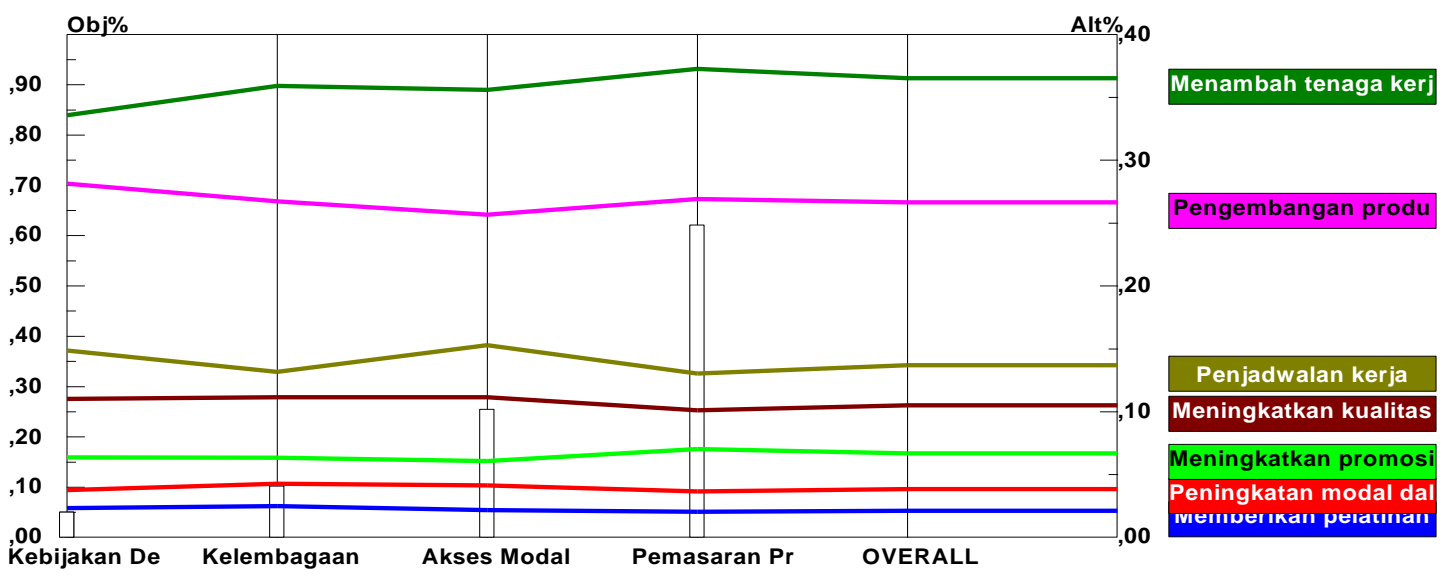

Gambar 5. Grafik hasil analisa strategi terpilih dengan metode AHP

Hasil akhir dari analisis hirarki proses (AHP) menunjukkan urutan prioritas seluruh alternatif pemilihan prioritas strategi pengembangan kegiatan ekonomi kreatif PKK di Kota Tabanan. Dari urutan terbesar sampai terkecil adalah menambah tenaga kerja distributor, Pengembangan produk ekonomi kreatif, Penjadwalan kerja, Meningkatkan kualitas produk ekonomi kreatif, Meningkatkan promosi melalui media sosial dan pemberian bonus dalam kegiatan ekonomi kreatif, Peningkatan modal dalam kegiatan ekonomi kreatif dan Memberikan pelatihan dan penyuluhan kegiatan ekonomi kreatif.

Terpilihnya menambah tenaga kerja distributor sebagai prioritas pertama dari ketujuh alternatif dalam pemilihan prioritas strategi pengembangan kegiatan ekonomi kreatif PKK di Kota Tabanan, ditinjau dari empat kriteria yaitu kebijakan desa, kelembagaan PKK, akses modal, dan pemasaran produk, dimana menambah tenaga kerja distributor produk ekonomi kreatif menjadi pilihan utama, dengan memiliki bobot, pemasaran produk sebesar 0,373, akses modal memiliki bobot dengan nilai sebesar 0,356, kelembagaan PKK memilik bobot dengan nilai sebesar 0,359 , dan kebijakan desa dengan bobot 0,336 .

Strategi menambah tenaga kerja distributor dilakukan untuk meningkatkan penjualan, dimana dalam pemasaran produk diperlukan keterjangkauan produk agar dapat diterima oleh konsumen dengan baik. Dengan adanya tenaga distributor yang handal sehingga dapat menunjang pendistribusian yang tepat dan konsumen dapat lebih mengenal hasil produk dari produsen dengan baik (Isnaini, 2019). Hal ini sejalan dengan penelitian terkait pentingnya saluran distribusi sebagai alat analisis bauran pemasaran yang dapat digunakan untuk menentukan berhasil tidaknya pemasaran yang dilakukan (Oktaviani, 2013; Suwarno, 2006).

Strategi pengembangan produk ekonomi kreatif menjadi prioritas kedua setelah strategi menambah tenaga kerja distributor. Hal ini berdasarkan pada kriteria kebijakan desa, pemasaran produk, kelembagaan PKK, akses modal menjadi proritas kedua dengan bobot berturut-turut 0,281; 0,$269 ; 0,267 ; 0,257$. Strategi pengembangan produk ekonomi kreatif merupakan salah satu cara dalam bertahan didalam persaingan usaha, dimana banyaknya pelaku usaha yang mencoba masuk didalam pasar produk ekonomi kreatif.

\section{KESIMPULAN}

Kondisi internal dalam mengembangkan kegiatan ekonomi kreatif PKK di Kota Tabanan, dimana faktor yang menjadi kekuatan utama yaitu kelembagaan kelompok yang solid. Untuk faktor kelemahan utama adalah kurangnya informasi mendapatkan kegiatan pelatihan dan Keterbatasan memperoleh modal. Selanjutnya Kondisi eksternal dalam mengembangkan kegiatan ekonomi kreatif PKK di Kota Tabanan, dimana faktor peluang yang baik yaitu kelompok PKK memiliki citra yang baik di pemerintahan desa. Untuk faktor ancaman yang besar yaitu kemudahan dalam duplikasi produk oleh pesaing. Sehingga didapatkan strategi tebaik yang dapat diterapkan dalam mengembangkan kegiatan ekonomi kreatif PKK di Kota Tabanan yaitu menambah tenaga kerja distributor untuk meningkatkan penjualan, dimana dalam pemasaran produk diperlukan keterjangkauan produk agar dapat diterima oleh konsumen dengan baik 


\section{REFERENSI}

Anisa, F. N., Gayatri, S., \& Dalmiyatun, T. (2020). Pengaruh Kepercayaan Anggota Terhadap Kohesivitas Kelompok Tani Sumber Rejeki Kelurahan Purwosari, Kecamatan Mijen, Kota Semarang. Agrisocionomics: Jurnal Sosial Ekonomi Pertanian, 4(1), 176-191. https://doi.org/10.14710/agrisocionomics.v4i1.6236

Badan Pusat Statistik Kabupaten Tabanan. (2020). Kecamatan Tabanan Dalam Angka 2020. Badan Pusat Statistik Kabupaten Tabanan. https:/tabanankab.bps.go.id/publication/2020/09/28/f7a5723b426bbc820f42cefd/kecamatantabanan-dalam-angka-2020.html

David, F. R. (2004). Manajemen Strategis Konsep-konsep Edisi Kesembilan. PT. Indeks. Jakarta.

Endang Purwanti. (2012). Pengaruh Karakteristik Wirausaha, Modal Usaha, Strategi Pemasaran terhadap Perkembangan UMKM di Desa Dayaan dan Kalilondo Salatiga. Jurnal Among Makarti, 5(9), 13-28. https://jurnal.stieama.ac.id/index.php/ama/article/view/65

Fukuyama, F. (2001). Social Capital, Civil Society and Development. Third World Quarterly, 22(1), 720. https://www.jstor.org/stable/3993342?seq=1

Harto, S., Garside, A. K., \& Utama, D. M. (2016). Penjadwalan Produksi Menggunakan Algoritma Jadwal Non Delay Untuk Meminimalkan Makespan Studi Kasus Di CV. Bima Mebel. SPEKTRUM INDUSTRI, 14(1), 79. https://doi.org/10.12928/si.v14i1.3706

Indarto, I., \& Santoso, D. (2020). Karakteristik Wirausaha, Karakteristik Usaha Dan Lingkungan Usaha Penentu Kesuksesan Usaha Mikro Kecil Dan Menengah. Jurnal Riset Ekonomi Dan Bisnis, 13(1), 54-69. https://doi.org/10.26623/JREB.V1311.2202

Indika, D. R., \& Jovita, C. (2017). Media Sosial Instagram Sebagai Sarana Promosi Untuk Meningkatkan Minat Beli Konsumen. Jurnal Bisnis Terapan, 1(01), 32. https://doi.org/10.24123/jbt.v1i01.296

Indrawati, K. A. P., Sudiarta, I. N., \& Suardana, I. W. (2017). Efektivitas Iklan Melalui Media Sosial Facebook Dan Instagram Sebagai Salah Satu Strategi Pemasaran Di Krisna Oleh-Oleh Khas Bali. Jurnal Analisis Pariwisata, 17(2), 78-83. https://ojs.unud.ac.id/index.php/jap/article/view/36484

Indriani, F. (2006). Studi Mengenai Orientasi Inovasi, Pengembangan Produk Dan Efektifitas Promosi Sebagai Sebuah Strategi Untuk Meningkatkan Kinerja Produk. Jurnal Studi Manajemen Organisasi, 3(2), 82-92. https://doi.org/10.14710/jsmo.v3i2.4191

Ishak, A. A. (2016). Eksplorasi Peluang Pasar Potensial Untuk Peningkatan Penjualan Produk UMKM. Sustainable Competitive Advantage (SCA), 6(1). http://jp.feb.unsoed.ac.id/index.php/sca-1/article/view/932

Isnaini, D. B. J. (2019). Efektivitas Peranan Saluran Distribusi Dan Hubungannya Terhadap Peningkatan Volume Penjualan Minyak Goreng Cap Sendok Pada PT. Astra Agro Lestari tbk. Medan. Wahana Inovasi: Jurnal Penelitian Dan Pengabdian Masyarakat UISU, 8(2), 13-20. https://jurnal.uisu.ac.id/index.php/wahana/article/view/2032

Istinganah, N. F., \& Widiyanto, W. (2020). Pengaruh Modal Usaha, Tingkat Pendidikan, dan Karakteristik Wirausaha Terhadap Perkembangan UKM. Economic Education Analysis Journal, 9(2), 438-455. https://doi.org/10.15294/EEAJ.V912.39293

Jamiatun, J., Nurunnisa, D. P. J. I., Rahmatika, N. W., Mar'ati, A. C., Al Aribah, S., \& Rusdiyana, E. (2018). Dinamika Dan Partisipasi Anggota Kelompok Wanita Tani Dalam Program Diversifikasi Olahan Pangan Fungsional di Desa Jimbaran, Margorejo, Pati. PRIMA: Journal of Community Empowering and Services, 2(2), 34. https://doi.org/10.20961/prima.v2i2.36116

Johnson, D. W., Johnson, F. P., \& Theresia, S. (2012). Dinamika Kelompok: Teori dan Keterampilan (9th $\quad$ ed.). $\quad$ PT Indeks. http://opac.lib.ugm.ac.id/index.php?mod=book_detail\&sub=BookDetail\&act=view\&typ=htmlext \&buku_id=317920\&obyek_id=1

Khamidi, S. (2013). Pengaruh Diversifikasi Produk Terhadap Penjualan (Studi Kasus Pada Perusahaan Konveksi "Faiza Bordir" Bangil - Pasuruan). Jurnal Administrasi Bisnis, 5(2). http://administrasibisnis.studentjournal.ub.ac.id/index.php/jab/article/view/240

Kristiansen, S., Furuholt, B., \& Wahid, F. (2003). Internet Café Entrepreneurs: Pioneers in Information Dissemination in Indonesia. The International Journal of Entrepreneurship and Innovation, 4(4), 251-263. https://doi.org/10.5367/000000003129574315

Kusumanigrat, H. (2009). Memberdayakan Ekonomi Rakyat Kecil. PT Remaja Rosdakarya Offset.

Marwanti, S., \& Astuti, I. D. (2012). Model Pemberdayaan Perempuan Miskinmelalui Pengembangan Kewirausahaan Keluargamenuju Ekonomi Kreatif Di Kabupaten Karanganyar. SEPA: Jurnal Sosial Ekonomi Pertanian Dan Agribisnis, 9(1), 134-144. 
https://webcache.googleusercontent.com/search?q=cache:7NICk04njO0J:https://core.ac.uk/d ownload/pdf/12346271. pdf $+\& c d=1 \&$ hl=id\&ct=clnk\&gl=id

Muljaningsih, S., Soemarno, S., Hadiwidjojo, D., \& Mustadjab, M. M. (2012). Faktor-Faktor Yang Mempengharuhi Minat Wirausaha Pengolahan Pangan Organik Pada Perempuan Tani Di Desa Wonokerto, Bantur, Malang. Wacana Jurnal Sosial Dan Humaniora, 15(2), 12-18. https://wacana.ub.ac.id/index.php/wacana/article/view/265

Nasution, R., Garside, A. K., \& Utama, D. M. (2017). Penjadwalan Job Shop Dengan Pendekatan Algoritma Artificial Immune System. Jurnal Teknik Industri, 18(1), 29. https://doi.org/10.22219/jtiumm.vol18.no1.29-42

Nurseto, S. (2018). Pengaruh Saluran Distribusi dan Promosi Terhadap Kinerja Pemasaran (Studi Kasus Pada UKM Furniture Kota Semarang). Jurnal Administrasi Bisnis, 5(2), 121-126. https://doi.org/10.14710/jab.v5i2.16237

Oktaviani, R. (2013). Strategi Distribusi Pada Perusahaan Garment Ranny Collection Klaten [Fakultas Ekonomi, Universitas Megeri Yogyakarta]. https://core.ac.uk/download/pdf/33513437.pdf

Purwono, J., Sugyaningsih, S., \& Novianti, R. (2008). Strategi Pengembangan Bisnis Bibit Tanaman Hutan (Kasus PT Sarbi Moerhani Lestari, Bogor). Jurnal Berkala Ilmu Ekonomi, 2(1), 34-54. https://doi.org/10.21107/NBS.V211.560

Putriyandari, R., Amran, A., Roisah, R., Komalasari, Y., \& Yuliyana, W. (2018). Implementasi Pemanfaatan Media Sosial dalam Meningkatkan Pendapatan di Lembaga Belajar SMART CLUB BANDUNG. Jurnal Pengabdian Kepada Masyarakat, 1(1), 15. https://doi.org/10.31294/JABDIMAS.V111.3057

Rangkuti, F. (2015). Analisis SWOT: Teknik Membedah Kasus Bisnis. Gramedia Pustaka Utama. Jakarta.

Reinhart Abedneju Sondakh, Endang Erawan, \& Sarwo Edy Wibowo. (2019). Pemanfaatan Media Sosial Instagram Pada Akun @Geprekexpress Dalam Mempromosikan Restoran Geprek Express. LImu Komunikasi, 7(1), 279-292. https://ejournal.ilkom.fisipunmul.ac.id/site/?p=3812

Romli, M. E. (2019). Kreativitas dan Inovasi Dalam Pemasaran Untuk Mempertahankan dan Mengembangkan Kinerja Merek. Jurnal Media Wahana Ekonomika, 16(3), 218. https://doi.org/10.31851/jmwe.v16i3.3422

Roslinda, E., Ekyastuti, W., \& Kartikawati, S. M. (2017). Social capital of community forest management on Nusapati Village, Mempawah District, West Kalimantan, Indonesia. Biodiversitas, 18(2), 548-554. https://doi.org/10.13057/biodiv/d180215

Sa'adah, U. W. (2020). Pengaruh Diversifikasi Produk dan Harga Terhadap Kepuasan pelanggan(Studi pada Pelanggan Toko Zeze Media Balung) [Universitas Muhammadiyah Jember]. http://repository.unmuhjember.ac.id/4951/

Saaty, T. L. (2008). Decision making with the Analytic Hierarchy Process. International Journal of Services Sciences, 1(1), 83-98. https://doi.org/10.1504/ijssci.2008.017590

Safitri, H., \& Setiaji, K. (2018). Pengaruh Modal Usaha Dan Karakteristik Wirausaha Terhadap Perkembangan Usaha Mikro Dan Kecil Di Desa Kedungleper Kecamatan Bangsri Kabupaten Jepara. Economic Education Analysis Journal, 7(2), 792-800. https://journal.unnes.ac.id/sju/index.php/eeaj/article/view/28291

Setiawan, I. M. D., Sukanteri, N. P., Suryana, I. M., \& Suparyana, P. K. (2019). Pengaruh Promosi Berbasis Sosial Media Terhadap Penjualan Produksi Kelompok Wanita Tani (KWT) Ayu Tangkas Di Desa Megati. Jurnal IImu Sosial Dan Humaniora, 8(2), 227-234. https://doi.org/10.23887/JISH-UNDIKSHA.V8I2.22375

Sugitarina, I. G. A. D., Darmawan, D. P., \& Astiti, N. W. S. (2016). Keberhasilan Program Kawasan Rumah Pangan Lestari (KRPL) pada Kelompok Wanita Tani di Kabupaten Gianyar. JMA: Jurnal Manajemen Agribisnis, 4(2), 133-146. https://ojs.unud.ac.id/index.php/agribisnis/article/view/27846

Suparyana, P. K., Sukanteri, N. P., \& Septiadi, D. (2020). Stategi Pengembangan Usaha Produksi Kue Pada Kelompok Wanita Tani Ayu Tangkas Di Kecamatan Selemadeg Timur, Bali. AGRISAINTIFIKA: Jurnal IImu-IImu Pertanian, 4(1), 46-59. https://doi.org/10.32585/ags.v4i1.844

Susanti, D., Rosyani, R., \& Suratno, T. (2018). Hubungan Tingkat Kepercayaan Anggota Dan Fungsi Kelompok Dengan Efektivitas Kelompok Tani Di Kelurahan Bagan Pete Kecamatan Kota Baru Kota Jambi. Jurnal IImiah Sosio-Ekonomika Bisnis, 19(2), 5. https://doi.org/10.22437/jiseb.v19i2.5021

Susatin. (2019). Strategi Tim Penggerak Pemberdayaan Dan Kesejahteraan Keluarga (PKK) Dalam Meningkatkan Program Kerja PKK Di Desa Gandoang Kecamatan Salem Kabupaten Brebes. 
Moderat: Jurnal IImiah Ilmu Pemerintahan, 5(2), 139-152. https://doi.org/http://dx.doi.org/10.25147/moderat.v5i2.2405

Suwarno, H. L. (2006). Sembilan Fungsi Saluran Distribusi: Kunci Pelaksanaan Kegiatan Distribusi yang Efektif. Jurnal Manajemen Maranatha, 6(1), 79-87. https://doi.org/10.28932/JMM.V6l1.227

Untari, D., \& Fajariana, D. I. (2018). Strategi Pemasaran Melalui Media Sosial Instagram (Studi Deskriptif Pada Akun @Subur_Batik).Widya Cipta - Jurnal Sekretari Dan Manajemen, 2(2), 271-278. https://doi.org/10.31294/WIDYACIPTA.V2I2.4387

Utama, D. M. (2016). Analisa Perbandingan Penggunaan Aturan Prioritas Penjadwalan Pada Penjadwalan Non Delay N Job 5 Machine. Prosiding SENTRA (Seminar Teknologi Dan Rekayasa), 0(2), 19-23. https://doi.org/10.22219/SENTRA.V0I2.1826

Utama, D. M. (2019). Penguatan Aspek Manajemen Produksi Dan Kualitas Tempe Pada UKM Tempe. JPPM (Jurnal Pengabdian Dan Pemberdayaan Masyarakat), 3(1), 133. https://doi.org/10.30595/jppm.v3i1.3641

Utama, I. D. (2019). Analisis Strategi Pemasaran Pada Usaha Mikro Kecil dan Menengah (UMKM) Pada Era Digital di Kota Bandung. EQUILIBRIUM: Jurnal Ilmiah Ekonomi Dan Pembelajarannya, 7(1), 1. https://doi.org/10.25273/equilibrium.v7i1.3829

Utari, T., \& Dewi, N. P. M. (2014). Pengaruh Modal, Tingkat Pendidikan dan Teknologi Terhadap Pendapatan Usaha Mikro Kecil dan Menengah (UMKM) Di Kawasan Imam Bonjol Denpasar Barat. E-Jurnal Ekonomi Pembangunan, 3(12), 549-623. https://ojs.unud.ac.id/index.php/eep/article/view/9916

Wuysang, R. (2014). Modal Sosial Kelompok Tani Dalam Meningkatkan Pendapatan Keluarga Suatu Studi Dalam Pengembangan Usaha Kelompok Tani Di Desa Tincep Kecamatan Sonder. ACta Diurna Komunikasi, https://ejournal.unsrat.ac.id/index.php/actadiurnakomunikasi/article/view/5637 